\title{
Organic Matter and Elemental Composition of Mudstones in the Member 3 of Paleogene Shahejie Formation in the Dongying Depression, Eastern China
}

\author{
Zhonghong Chen ${ }^{1,2 *}$, Qing Liư ${ }^{3}$, Shouchun Zhang3, Chunxue Jiang2 \\ ${ }^{1}$ State Key Laboratory of Petroleum Resources and Prospecting, Faculty of Natural Resources and Information \\ Technology, China University of Petroleum, Beijing, China \\ ${ }^{2}$ School of Geoscience, China University of Petroleum, Qingdao, China \\ ${ }^{3}$ Geological Scientific Research Institute, Shengli Oilfield Company, SINOPEC, Dongying, China \\ Email: hongczh@163.com
}

Received 5 May 2015; accepted 6 June 2015; published 9 June 2015

Copyright (C) 2015 by authors and Scientific Research Publishing Inc.

This work is licensed under the Creative Commons Attribution International License (CC BY).

http://creativecommons.org/licenses/by/4.0/

(c) (i)

\section{Abstract}

The organic matter distribution and hydrocarbon generation potential as well as element distribution in the lacustrine mudstones of lower Member 3 of Paleogene Shahejie Formation in the Dongying depression, eastern China were investigated using methods of Rock-Eval pyrolysis, inductively coupled plasma emission spectrometer. The results show that most of the samples are high-quality source rocks with high TOC and $S_{2}$, and the oil shale samples are excellent source rocks with the TOC and $S_{2}$ greater than $5.0 \%$ and $20.0 \mathrm{mg} / \mathrm{g}$, respectively. A freshwater depositional environment in the deep lake for the mudstones was indicated by lower values of biomarker ratios gammacerane $/ C_{30}$ Hopane and $C_{35}$ Hopane $/ C_{34}$ Hopane. With the lacustrine regression, the ratios $\mathrm{Ca} / \mathrm{U}, \mathrm{Ca} / \mathrm{Ba}, \mathrm{Ca} / \mathrm{Mg}$, $\mathrm{Ca} / \mathrm{B}, \mathrm{Ca} / \mathrm{Li}, \mathrm{Ca} / \mathrm{Sr}$ and $\mathrm{Sr} / \mathrm{Ba}$ decrease, while $\mathrm{Fe} /(\mathrm{Ca}+\mathrm{Mg}$ ) increases. In the section 3330 - $3370 \mathrm{~m}$ with enrichment of oil shale, the organic matter and inorganic elements present strong fluctuation. The quantitative relations among $\mathrm{U}, \mathrm{U} / \mathrm{Th}$ and TOC, $S_{2}, \% \mathrm{Ca}$ are divided into two parts at boundary values of $7.0 \%, 32 \mathrm{mg} / \mathrm{g}$ and $11 \%$ for TOC, $S_{2}$ and \%Ca, respectively.

\section{Keywords}

Organic Matter, Mudstone and Shale, Element, Uranium, Lacustrine Basin

\footnotetext{
${ }^{*}$ Corresponding author.
} 


\section{Introduction}

Dongying Depression is a typical negative rift tectonic unit located at the southern part of the Bohai Bay Basin and characterized as northern faulted, southern overlapped and opening shaped (Figure 1) [1]. The depression developed from ancient Paleozoic bedrock with various tectonic movements, and covers an area of $5700 \mathrm{~km}^{2}$ [2]. A set of clastic materials were deposited in the Paleogene system and dominated by mudstone intermixed with sandstone, carbonate and gypsum-salt rocks [3]. Under the influence of tectonic movement, the Paleogenesediments underwent three sedimentary processes, namely: salted lake, deep lacustrine and river delta. Dark mudstone and shale were mainly deposited in the lower parts of Member $3\left(\mathrm{Es}_{3}^{1}\right)$ of the Paleogene Shahejie Formation. The study on geochemistry of inorganic elements and organic matter can help to improve the understanding of the sedimentary environment and hydrocarbon generation potential of these mudstones.

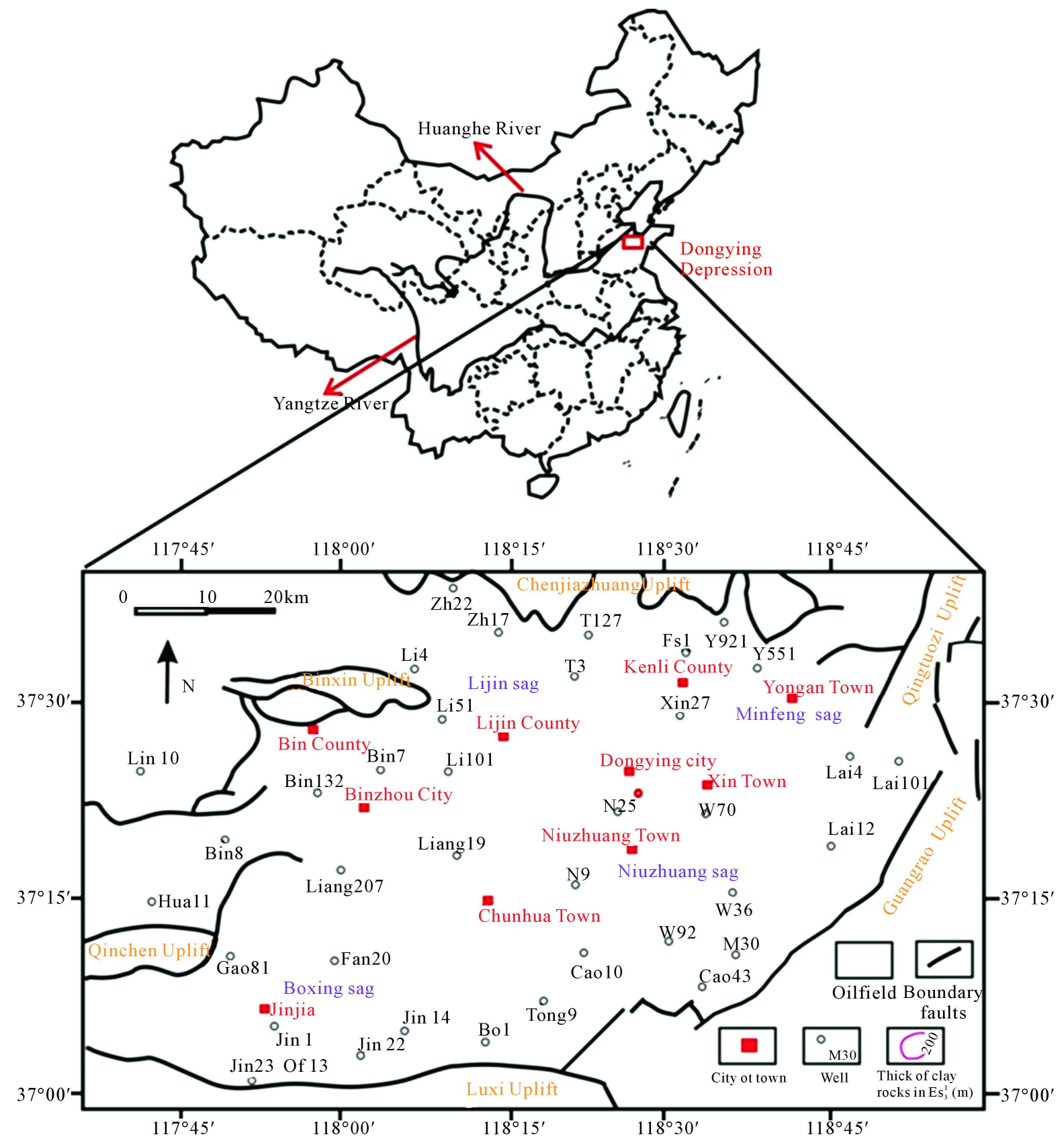

Figure 1. Sketched map showing the location and field geology of the Dongying Depression. 
In lake basin, the symbiotic relationship of uranium and organic matter has been an important topic [4]-[6]. Uranium (U) and Organic-richdeposits form under different lake conditions regardless of lake depth, but large anoxic lakes provide the most favorable environment [7]. Highly preserved organic matter deposits are most likely to form in deep, alkaline lakes during humid and warm climate intervals, which are periods of high lake levels [8] [9]. U found in environmental systems predominantly exists as $U(I V)$ and $U(V I)$ in variable subsurface sediments [10], and U(IV) is primarily found in reduced environments as the mineral uraninite $\left[\mathrm{UO}_{2}(\mathrm{~s})\right]$; other U(IV) species have also been reported to exist in reduced environments [10] [11]. There used to be thought that under reducing environments, the capacity of OM to adsorb $\mathrm{U}$ increases with increasing in total organic carbon content (TOC) [5] [12], as strongly acidic environments are conducive to the enrichment of $\mathrm{U}^{4+}$, which is hydrolyzed to $\mathrm{U}^{6+}$ when the level of acidity is decreased [4] [6]. Reducing sedimentary environment seems to be beneficial to the enrichment of both uranium and organic matter, while detail and quantitative relationship between $\mathrm{U}$ and TOC was rarely recorded.

The Dongying Depression is a typical terrestrial rift lake basin in China that holds large amounts of lacustrine mudstones in the Paleogene Member 3 [1] [2]. In this study, we investigate geochemistry of organic matter and element compositions on the samples from a continuous core section of mudstones in a well in this depression. The data show the relationships among $\mathrm{U}$, organic carbon, and inorganic elements (e.g., $\mathrm{Ca}$ ) and provides a high-resolution record of the fluctuations in the paleo sedimentary environment of the terrestrial lake basin.

\section{Samples and Experiment Methods}

The samples were collected from the N-38 Well is located in the south part of Dongying Depression, Bohai Bay Basin, eastern China (Figure 1). This well was continuously cored from mudstones in the interval 3190 - 3376 $\mathrm{m}$. This interval was in a strongly reducing deep-lake environment, developed dark gray mudstone, calcareous mudstone and various fossils, including abundant ostracods, sporopollenin and algae [1]. A set of samples from the cores were tested and analyzed. The organic and inorganic geochemistry of the mudstones as well as the relationships among $\mathrm{U}$, organic carbon, and inorganic elements (e.g., $\mathrm{Ca}$ ) were investigated.

A total of 124 samples were analyzed via Rock-Evalpyrolysis. Among these, 21 samples with inorganic element contents were tested by using an inductively coupled plasma emission spectrometer, 14 samples with kerogen contents were examined with micro components, and 20 samples were detected with biomarkers.

The Rock-Eval pyrolysis method has been extensively used for oil and gas explorations in sedimentary basins worldwide. This method involves estimating the petroleum potential of sedimentary rocks by heating samples in an open pyrolysis system under non-isothermal conditions. The released hydrocarbons are monitored by using a flame ionization detector, which forms the so-called peaks $S_{1}$ (thermovaporized free hydrocarbons) and $S_{2}$ (pyrolysis products from cracking of organic matter). The temperature at which the maximum amount of $S_{2}$ hydrocarbons is generated is called $T_{\max }$. $T_{\max }$ represents the temperature at which the maximum release of hydrocarbon from the cracking of kerogen occurs during pyrolysis (top of $S_{2}$ peak). $T_{\max }$ indicates the maturation stage of organic matter. Several pyrolytic parameters were calculated directly. Oil production potential, which represents residual hydrocarbon generation potential, is directly calculated as $P g=S_{1}+S_{2}$. The hydrogen index $\left(I_{\mathrm{H}}=[100\right.$ $\left.\times S_{2}\right] /$ TOC $)$ is a parameter used to characterize organic matter origin. The production index $\left(I_{\mathrm{P}}\right)\left(I_{\mathrm{P}}=S_{1} /\left[S_{1}+S_{2}\right]\right)$ is used to characterize the evolution level of organic matter.

Dichloromethane was used as solvent for $72 \mathrm{~h}$ of continuous extraction at a constant temperature of $70^{\circ} \mathrm{C}$ in a Soxhlet apparatus. The solvent was evaporated until it dried out. Approximately $10-15 \mathrm{mg}$ extract was dissolved by adding petroleum ether $(100 \mathrm{~mL})$, repeatedly washed, transferred in a flask, left to stand for $24 \mathrm{~h}$ and filtered. The soluble portion was a mixture of saturated and aromatic hydrocarbons and non-hydrocarbons.

In the biomarker analysis, chloroform was used as solvent for $72 \mathrm{~h}$ of continuous extraction at a constant temperature of $70^{\circ} \mathrm{C}$ in a Soxhlet apparatus and then evaporated to dryness. A silica-alumina column was used to separate the saturated hydrocarbons, aromatic hydrocarbons, and nonhydrocarbons from the soluble extract.

An HP-Chemstation gas chromatography-mass spectrometry (GC-MS) analyzer was used (GC model HP5890 II and MS model HP-5890A; column, DB5-MS; column length, $60 \mathrm{~m}$; and internal diameter, $0.25 \mathrm{~mm}$ ). The initial temperature of $100^{\circ} \mathrm{C}$ was increased to a final temperature of $320^{\circ} \mathrm{C}$ at a heating rate of $4.0^{\circ} \mathrm{C} / \mathrm{min}$. The temperature of gasification and the transmission line was $310^{\circ} \mathrm{C}$, the ion source temperature was $250^{\circ} \mathrm{C}$, and the pre-column pressure was $170 \mathrm{kPa}$. The split ratio was 20: 1 , and helium was the carrier gas. The electron energy was $70 \mathrm{eV}$, the scan rate was $0.46 \mathrm{can} / \mathrm{s}$, and electron-impact ionization was employed. Biomarkers were 
identified using the mass fragmentogram and relative retention time in comparison with the standard sample. Biomarkers were quantified using the peak area responses of specific mass chromatogram peaks $(\mathrm{m} / \mathrm{z} 191$ and $\mathrm{m} / \mathrm{z} 217)$.

Gamma ray (GR) logging and natural gamma spectrometry (NGS) logging were performed in the Niu-38 well by the Sinopec Shengli oilfield co., LTD, which provides the data of U, Th and GR. The GR and U curves were drawn from the logging data in the $\mathrm{Es}_{3}$.

\section{Results}

\subsection{U and Th Distribution}

The radioactive elements $U$ and thorium (Th) are in the range of $2.12-5.21 \mathrm{ug} / \mathrm{g}$ and $3.56-9.19 \mathrm{ug} / \mathrm{g}$ with average values of $3.52 \mathrm{ug} / \mathrm{g}$ and $7.0 \mathrm{ug} / \mathrm{g}$, respectively. The logging curves of GR, $U$ and Th display significant variation curve. Comparatively, the oil shale shows characteristics of high natural gamma ray and uranium content, high resistivity (RT), high interval transit time, low density and Th contents on the well logging curves, especially the high content of $U$ in the oil shale is remarkable (Figure 2). This is because organic matter is conducive to the enrichment of $U$, as oil shale usually has higher content of organic matter than massive mudstone.

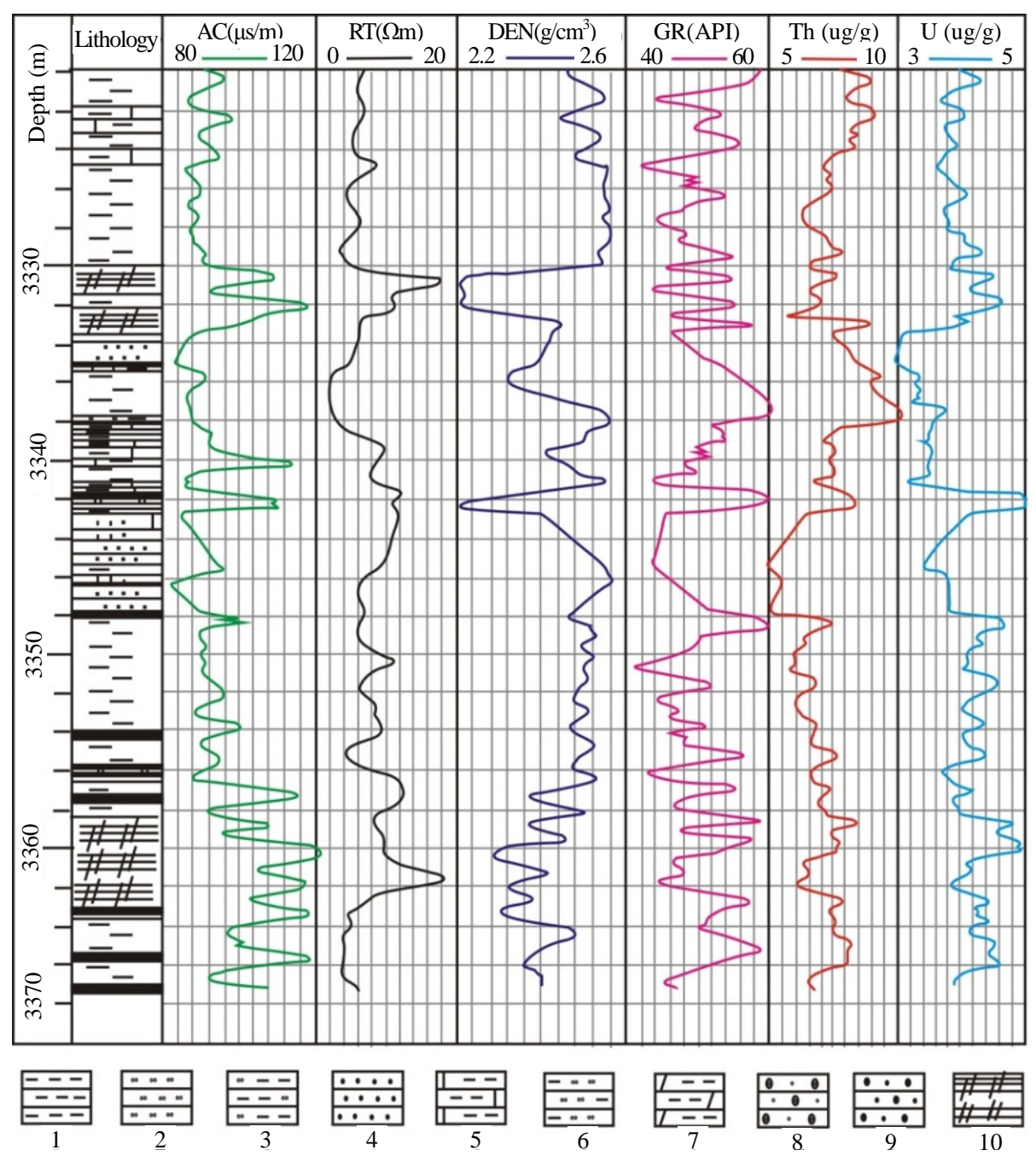

Figure 2. Well logging response of the mudstones and oil shales showing the distribution of uranium and thorium in the N38 Well. 1, mudstone; 2, siltstone; 3, silty mudstone; 4, fine sandstone; 5 , calcilutite; 6 , argillaceous siltstone; 7 , dolomite mudstone; 8 , oolitic sandstone; 9 , medium-fine sandstone; and 10, oil shale. 


\subsection{Inorganic Element Distribution}

The concentrations of Ca, Sr, Ba and B in the 3330 - $3370 \mathrm{~m}$ are higher compared to those in the 3190 - $3330 \mathrm{~m}$, and the average content of $\mathrm{Ca}, \mathrm{Sr}, \mathrm{Ba}$ and $\mathrm{B}$ are $9.14 \%, 667.1 \mathrm{ug} / \mathrm{g}, 487.1 \mathrm{ug} / \mathrm{g}$ and $52.6 \mathrm{ug} / \mathrm{g}$, respectively; the concentrations of $\mathrm{Mg}, \mathrm{Fe}, \mathrm{Li}$ and $\mathrm{Zn}$ in the 3330 - $3370 \mathrm{~m}$ are lower, and their averages are $0.87 \%, 2.61 \%, 1.47$ ug/g and 51 ug/g, respectively (Figure 3). As depth decreases in 3190 - 3330 m, the concentrations of Ca and Sr

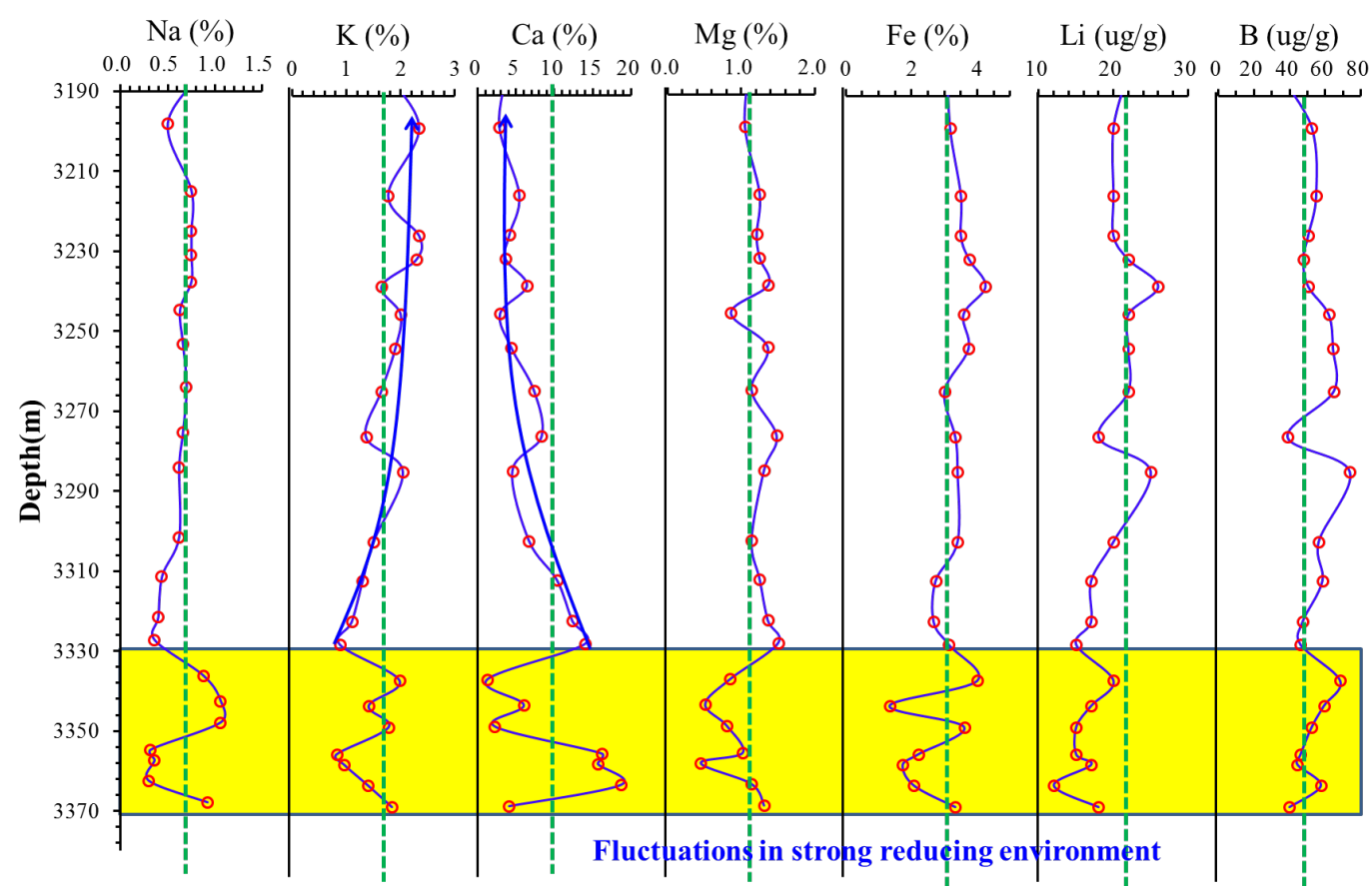

(a)

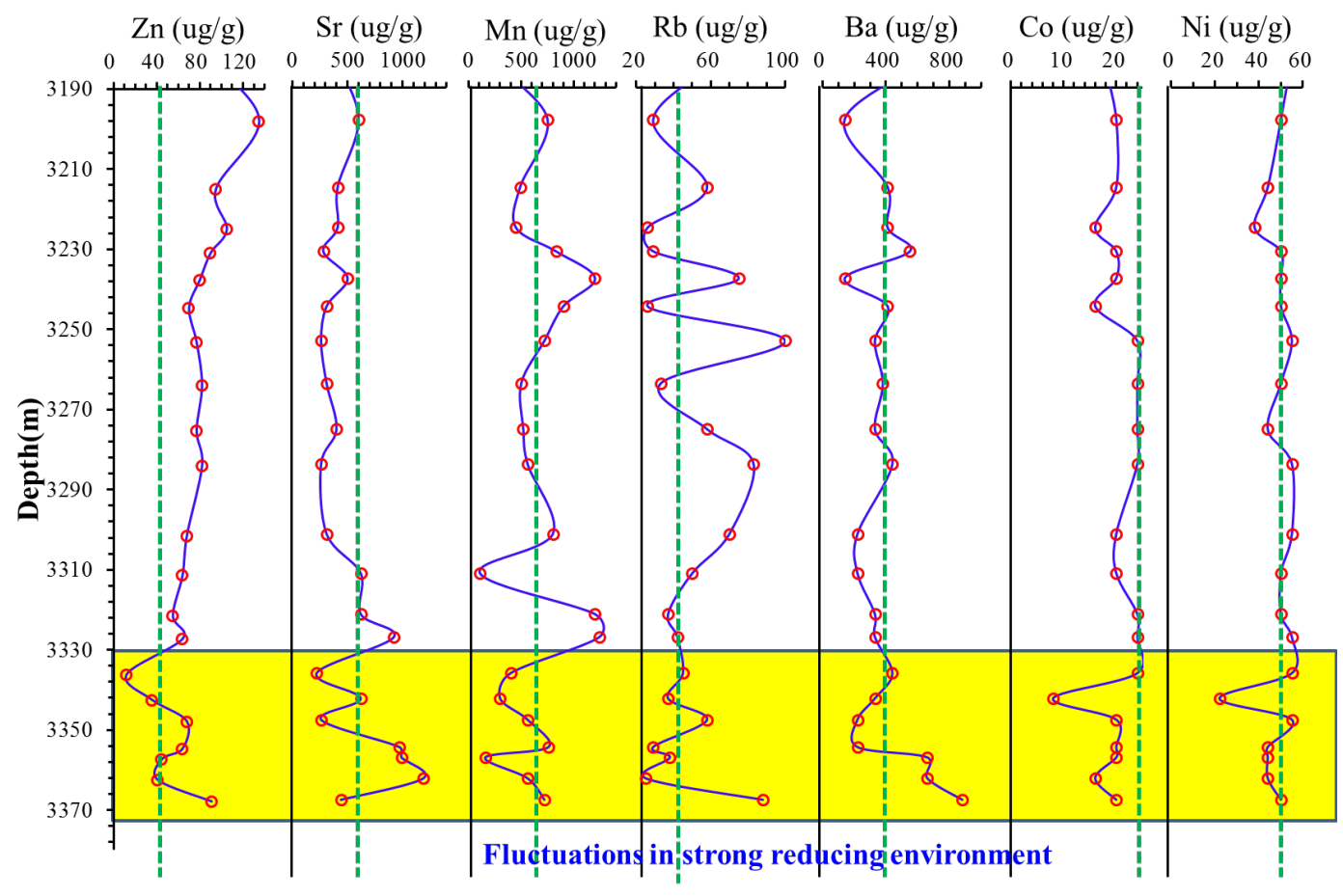

(b)

Figure 3. Inorganic elements of mudstones in the lower Member 3 of Paleogene Shahejie Formation of N38 well. 
decrease, the concentrations of $\mathrm{Zn}$ and $\mathrm{K}$ increase, while the other elements show little change, notwithstanding the data showing an abnormal distribution because of volatility during deposition, high concentrations of $\mathrm{Ca}$ and $\mathrm{Sr}$ can be found in the deep lake basin.

Overall the measured elements in the 3330 - $3370 \mathrm{~m}$ show characteristics of frequent change in the vertical distribution with burial depth, which indicates a fluctuation deposition of deep lake facies. The element ratios also show volatile changes (Figure 4). In the 3190 - $3330 \mathrm{~m}$, except $\mathrm{Fe} /(\mathrm{Ca}+\mathrm{Mg}$ ), the ratios $\mathrm{Ca} / \mathrm{U}, \mathrm{Ca} / \mathrm{Ba}$, $\mathrm{Ca} / \mathrm{Mg}, \mathrm{Ca} / \mathrm{B}, \mathrm{Ca} / \mathrm{Li}, \mathrm{Ca} / \mathrm{Sr}$ and $\mathrm{Sr} / \mathrm{Ba}$ all display overall gradual decrease with decreasing burial depth.

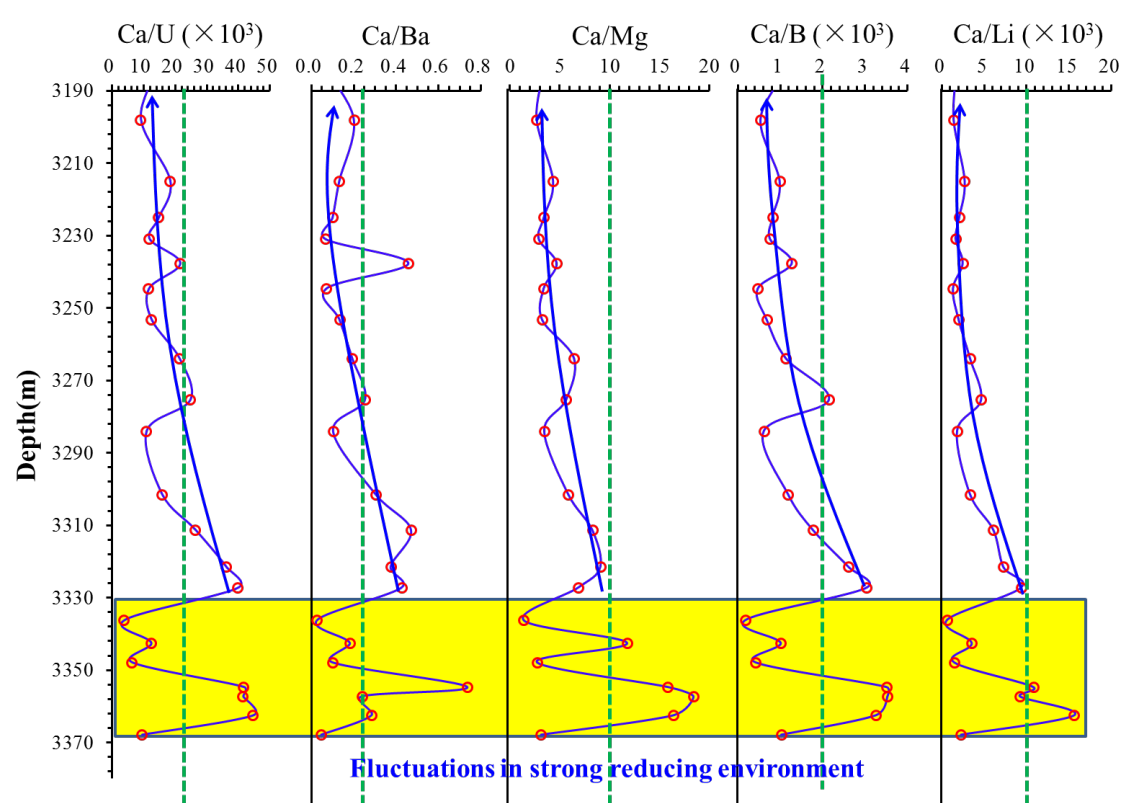

(a)

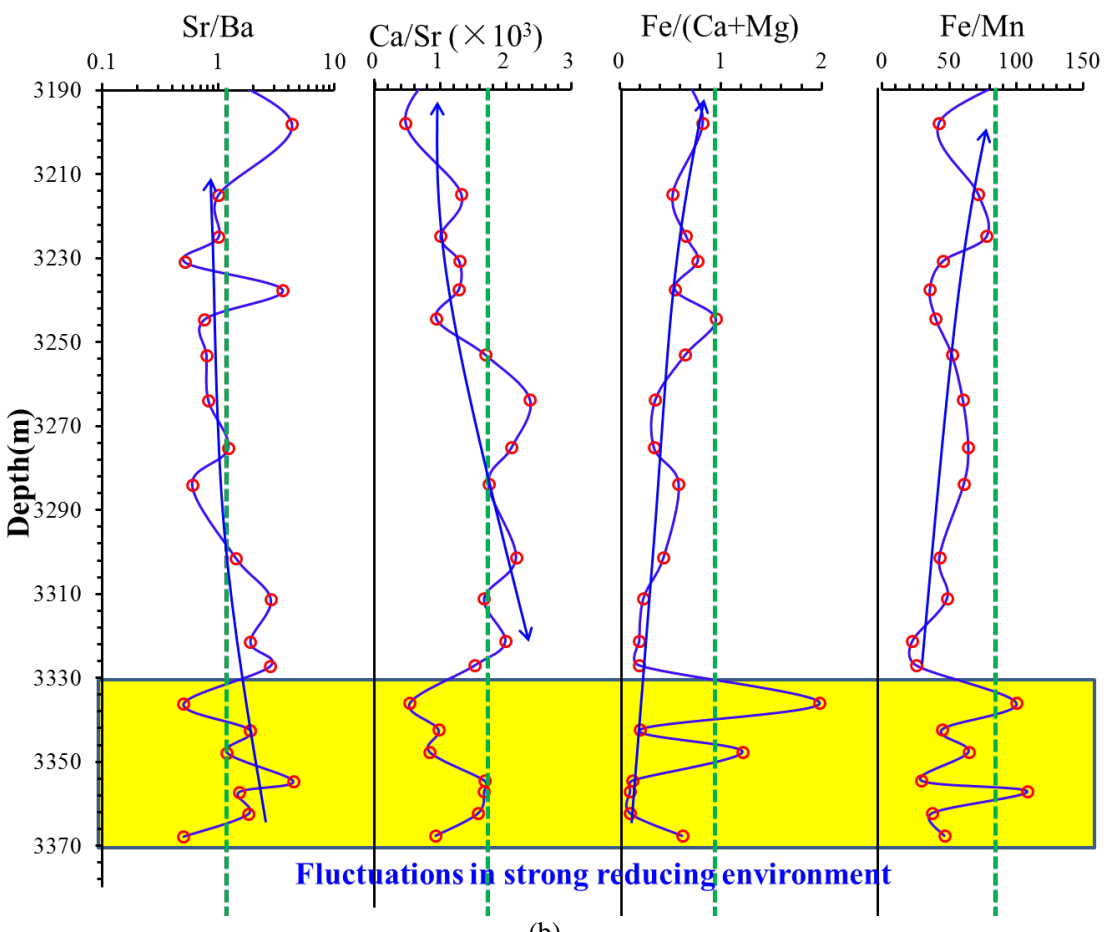

(b)

Figure 4. Element ratios of mudstones in the lower Member 3 of Paleogene Shahejie Formation of N38 well. 


\subsection{Distributions of TOC, $\mathrm{S}_{1}$, and $\mathrm{S}_{2}$}

The results of TOC and Rock-Evalparameters are presented in Figure 5. TOC values vary from 1.02 to $13.75 \%$, with an average of $3.65 \%$. The $S_{1}$ and $S_{2}$ distributed at the ranges $0.15-8.75 \mathrm{mg} / \mathrm{g}$ and $2.11-64.74 \mathrm{mg} / \mathrm{g}$ with averages of 1.95 and $18.68 \mathrm{mg} / \mathrm{g}$, respectively. Most samples show values of TOC and S2 being more than 2.0\% and $10 \mathrm{mg} / \mathrm{g}$, respectively, indicating the mudstone as effective source rocks. The parameters $I_{\mathrm{H}}$ and $I_{\mathrm{P}}$ distributed at $206.8-619.8 \mathrm{mg} / \mathrm{g}$ and $0.039-0.167$ with average values of $496.2 \mathrm{mg} / \mathrm{g}$ and 11.1 respectively. The $T_{\max }$ distributed at $434^{\circ} \mathrm{C}-448^{\circ} \mathrm{C}$, reflecting the mudstone and shale being moderately mature. Microscopic components of organic matter showed that the sapropel components are in high content $(72.7 \%-99.7 \%)$, and was dominated with organic matter of type I, and some of II1 type (Figure 6). With increasing depth, the samples show an overall increase in the content of sapropel and decrease in the content of exinite and vitrinite, and the inertinite remains at a very low content. This indicates that, on the whole, the quality of the hydrocarbon source rocks is getting better and better with increasing burial depth.

\subsection{Biomarkers}

The hopane $(\mathrm{m} / \mathrm{z}=191)$ and $\mathrm{C}_{27-29}$ sterane $(\mathrm{m} / \mathrm{z}=217)$ biomarkers are abundant in the samples. The ratios $\alpha \alpha \alpha-20 \mathrm{R}-\mathrm{C}_{29} / \mathrm{C}_{28}$ are in the range of $1.39-3.45$, and the $\alpha \alpha \alpha-20 \mathrm{R}-\mathrm{C}_{27} / \mathrm{C}_{28}$ are mostly in the range of $11.39-2.57$, this indicating characteristic of lacustrine organic matter input as the $\mathrm{C}_{28}$ steranes are very low compared to the $\mathrm{C}_{27}$ and $\mathrm{C}_{29}$ steranes. The values of gammacerane/ $\mathrm{C}_{30} \mathrm{H}$ (Hopane) and the $\mathrm{C}_{35} \mathrm{H} / \mathrm{C}_{34}$ Hare lower than 0.1 and 0.08 , respectively (Figure 7). This result is likely to indicate a freshwater depositional environment in deep lake basin as high abundance of gammacerane and $\mathrm{C}_{35}$ hopane is typical of evaporitic or high salinity environments [13] [14]. The thermal maturity parameters $C_{29} \beta \beta /(\beta \beta+\alpha \alpha)$ and $C_{29} 20 S /(20 S+20 R)$ are in the ranges of $0.29-0.49$ and $0.34-0.5$, respectively, showing a moderate maturation state. The ratio $\mathrm{Ts} /(\mathrm{Ts}+\mathrm{Tm})$ shows overall higher values and significant variation in the upper strata $(3190$ - $3290 \mathrm{~m})$ compared to the lower part (3290 - $3376 \mathrm{~m})$, this suggesting that although $\mathrm{Ts} /(\mathrm{Ts}+\mathrm{Tm})$ is commonly used as a parameter of maturity, it is tend to depend on organic facies, and compared to the thermal maturity parameters $\mathrm{C}_{29} \beta \beta /(\beta \beta+\alpha \alpha)$ and $\mathrm{C}_{29}-20 \mathrm{~S} /(20 \mathrm{~S}+20 \mathrm{R})$ this ratio seems to be more sensitive to clay minerals. Comparatively, the thermal maturity $\mathrm{C}_{31} 22 \mathrm{~S} /(22 \mathrm{~S}+22 \mathrm{R})$ and $\mathrm{C}_{32} 22 \mathrm{~S} /(22 \mathrm{~S}+22 \mathrm{R})$ show very little change in distributions with the range of $0.56-0.59$ and $0.57-0.58$, respectively.

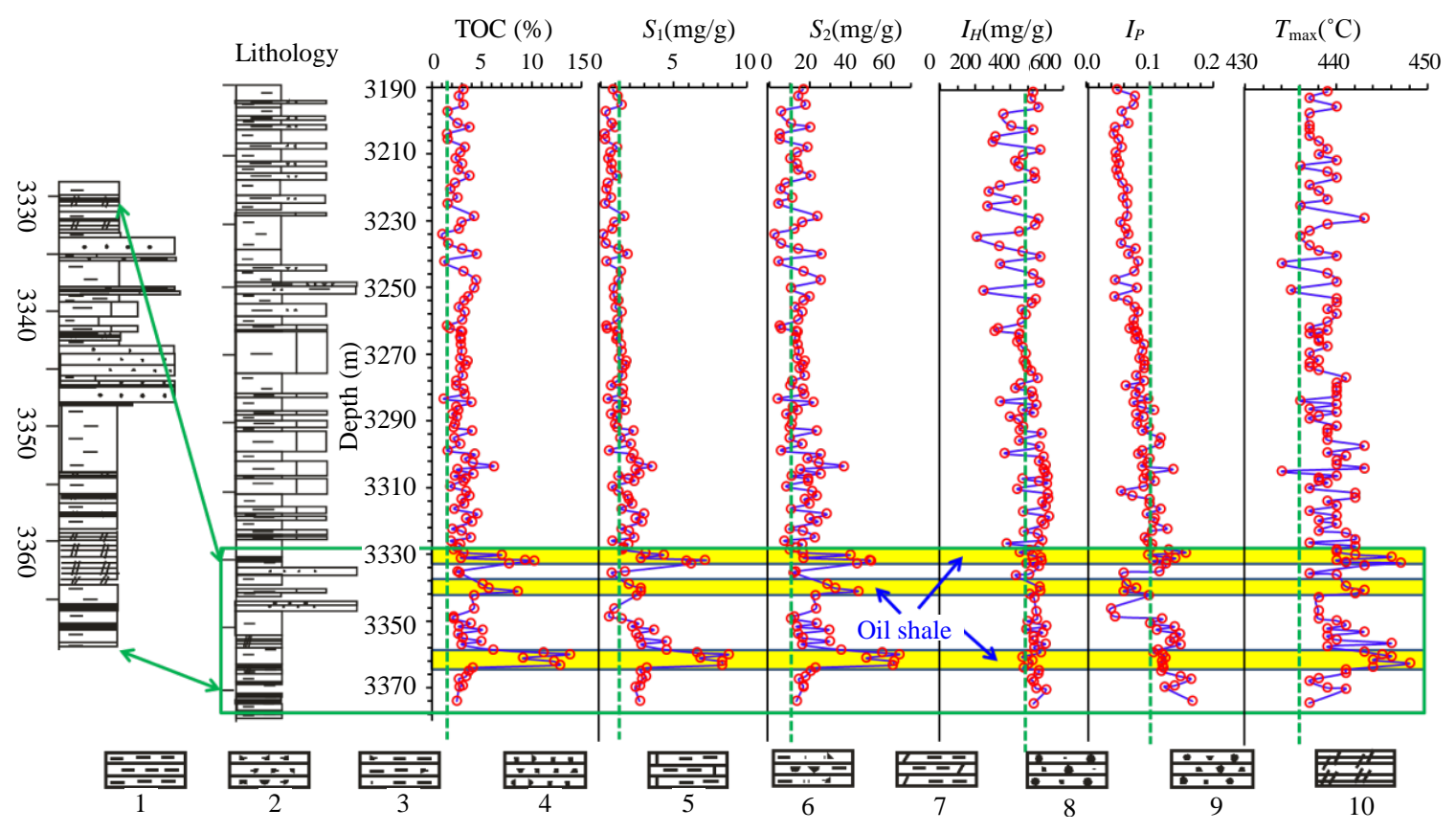

Figure 5. Distributions of the parameters obtained from the pyrolysis of mudstones in the lower Member 3 of PaleogeneShahejie Formation of the N38 well. 1, mudstone; 2, siltstone; 3, silty mudstone; 4, fine sandstone; 5 , calcilutite; 6 , argillaceous siltstone; 7 , dolomite mudstone; 8 , oolitic sandstone; 9 , medium-fine sandstone; and 10 , oil shale. 


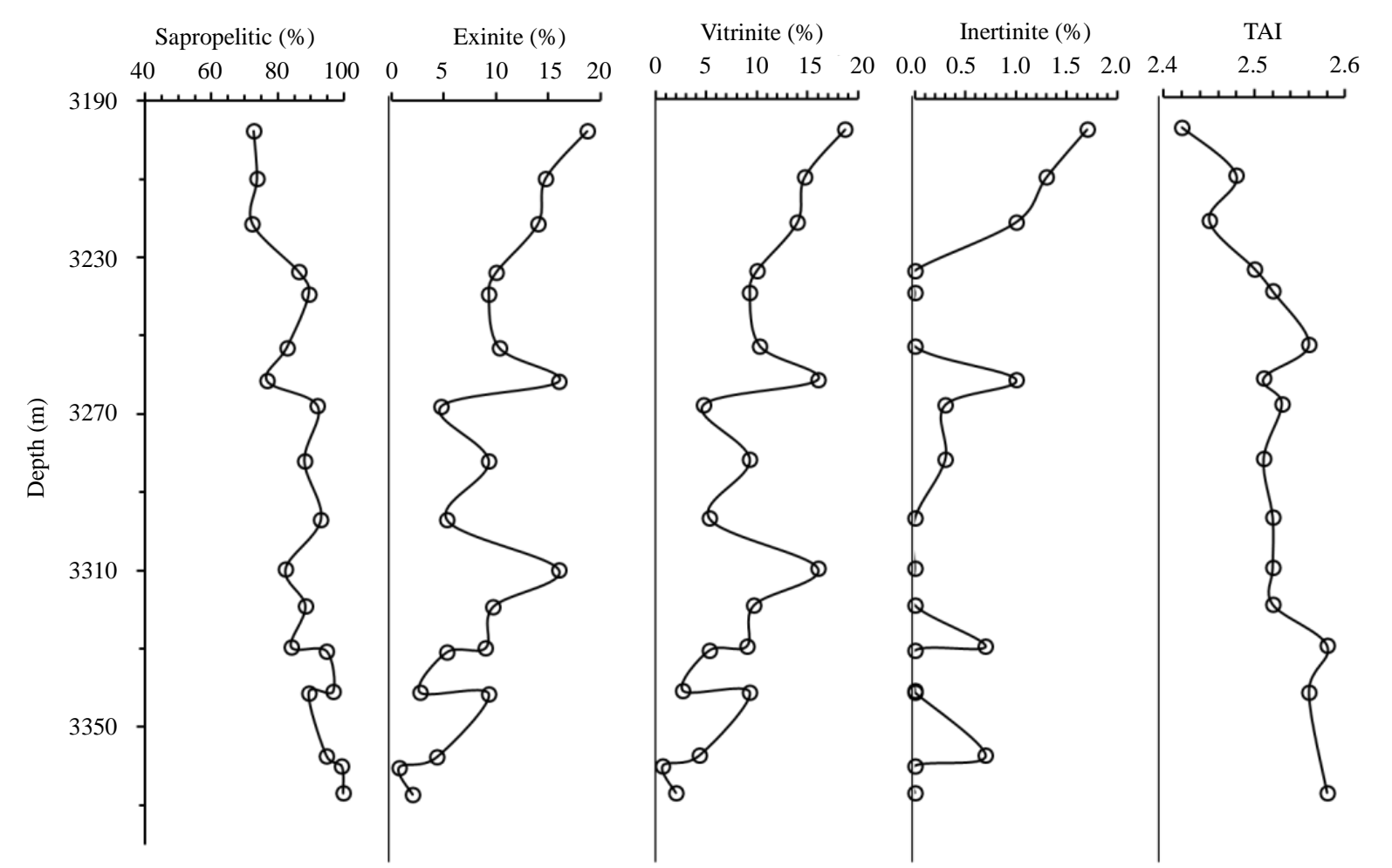

Figure 6. Distributions of the maceral of organic matter in the mudstones in the lower Member 3 of Paleogene Shahejie Formation of the N38 well.

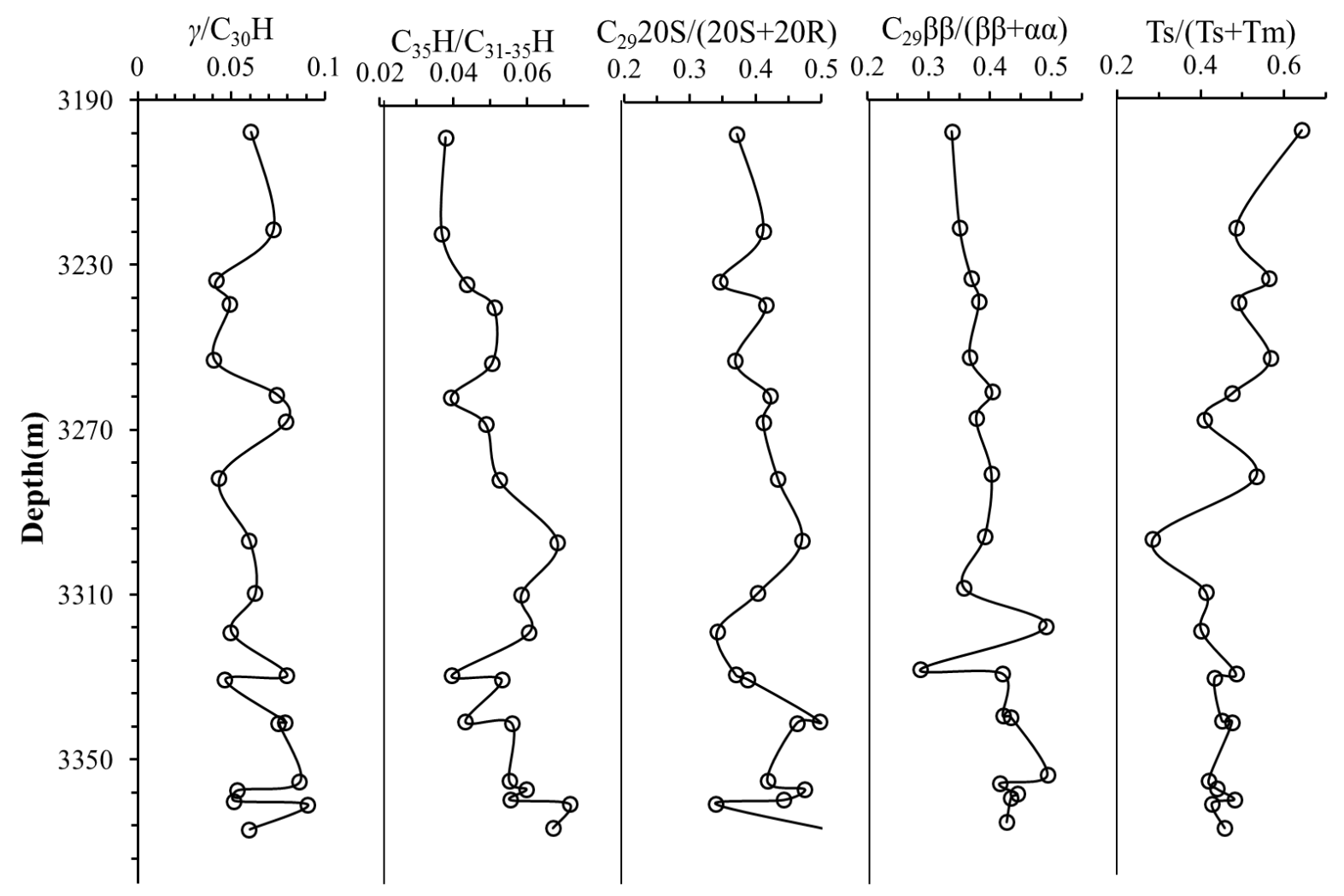

Figure 7. Distribution of biomarker parameters in the lower Member 3 of Paleogene Shahejie Formation of the N38 well. 


\section{Discussion}

\subsection{Fluctuation of Sedimentary Environment}

The inorganic elements and element ratios indicated a sedimentary process of deep lake gradually evolution to half deep lake with the uplift of lake basin and retreat of lake water (Figure 4). Take the $\mathrm{Fe} /(\mathrm{Ca}+\mathrm{Mg})$ as an example. Fe is relatively enriched in terrigenous clastic rocks, whereas $\mathrm{Ca}$ and $\mathrm{Mg}$ mainly occur in mudstone and carbonate rocks in deep water [15]. Thus, the $\mathrm{Fe} /(\mathrm{Ca}+\mathrm{Mg})$ ratio can also reflect the changes in water depth, with a high $\mathrm{Fe} /(\mathrm{Ca}+\mathrm{Mg})$ value indicating deep water. The data here shows that $\mathrm{Fe} /(\mathrm{Ca}+\mathrm{Mg})$ generally increase in the $\mathrm{Es}_{3}^{1}$ with decreasing burial depth with few exceptional abnormal data, indicating uplift of the lake basin and the gradually decreases of water depth. The organic and inorganic geochemistry parameters show the deposition of these deep lake sediments is not stable, and this is supported by the sedimentary structure of the fine sediments in the $E s_{3}^{1}$, which are mixed of laminated mudstone and shale with thin layers of siltstone, fine sandstone, or argillaceous siltstone.

\subsection{Source Rocks Characteristic}

The type of organic matter in petroleum source rocks can be characterized from $I_{\mathrm{H}}$ and $T_{\max }$. The intersection chart of $T_{\max }$ with $I_{\mathrm{H}}$ shows all samples are I or II1 type of organic matter, and is at the mature stage (Figure 8(a)). The intersection chart of $S_{2}$ and TOC shows that most of the samples TOC and $S_{2}$ are greater than $2.0 \%$ and $10.0 \mathrm{mg} / \mathrm{g}$, respectively, suggesting very good source rocks; a lot of samples even shows the TOC and $S_{2}$ are greater than $5.0 \%$ and $20.0 \mathrm{mg} / \mathrm{g}$, respectively, indicating excellent source rocks (Figure 8(b)). However, the macroscopic heterogeneity distribution of organic matter is also very significant, even in the layer with high TOC, the distribution of organic carbon have larger discrete. In the 3330 - $3370 \mathrm{~m}$, TOC and $S_{2}$ distribute in the range from $2.11 \%-13.75 \%$ and $10.46-64.14 \mathrm{mg} / \mathrm{g}$, respectively, reflecting a strong fluctuation. Oil shale shows relatively higher TOC and hydrocarbon generation potential and the TOC, $S_{2}$ and $I_{\mathrm{H}}$ are greater than 5.0\%, $10 \mathrm{mg} / \mathrm{g}$ and $500 \mathrm{mg} / \mathrm{g}$, showing the thin layers of oil shale with high TOC are high-quality hydrocarbon source rocks.

\subsection{Redox Conditions and U Enrichment}

Research shows the enrichment of $U$ can be accelerated under an anoxic environment because organic matter adsorption capacity of the $U$ will increase under this condition [12] [16]. For example, a strongly acidic environment is conducive to the enrichment of $\mathrm{U}^{4+}$, which is hydrolyzed to $\mathrm{U}^{6+}$ when the level of acidity weakens [4] [6]. It is possible to distinguish redox environments by evaluation TOC and $I_{\mathrm{H}}$. This study presents a high TOC

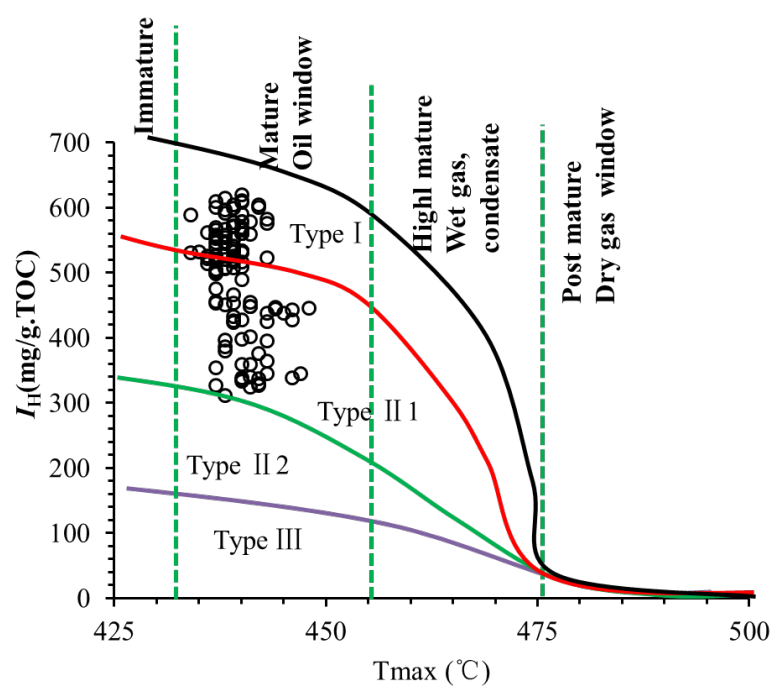

(a)

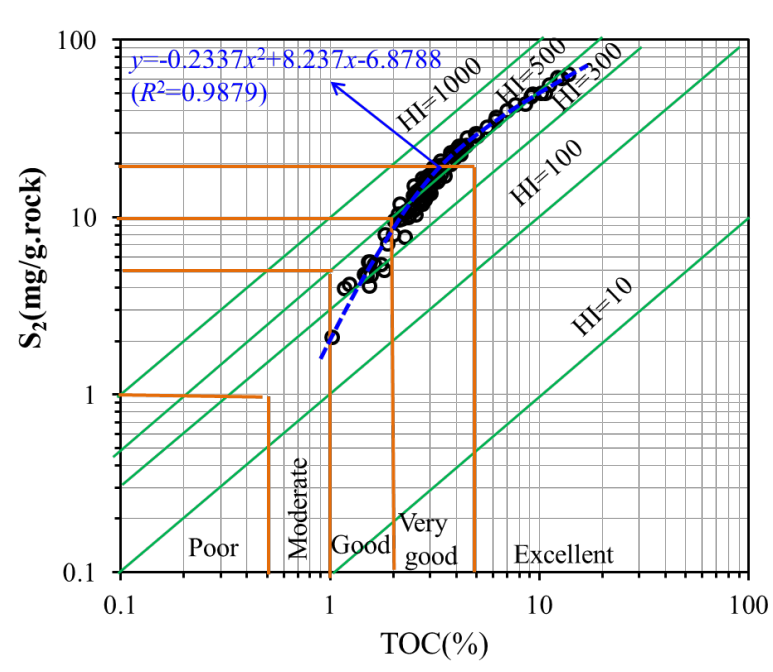

(b)

Figure 8. Cross plot of $I_{\mathrm{H}}$ and $T_{\max }$ (a) or TOC and $S_{2}$ (b) for the lacustrine mudstones and shales of the N38 well at depths 3190 - 3376 m. 
and $S_{2}$ distribution in the studied interval, which are generally greater than $2.0 \%$ and $100 \mathrm{mg} / \mathrm{g}$ rock, especially in the burial depth more than $3250 \mathrm{~m}$, although there is heterogeneity in their distributions. The high TOC and $S_{2}$ reflect that the organic matter type are dominated by types I and II1, which manifested an anoxic environment with favorable preservation conditions for organic matter. An interesting observation is that the correlation between the elevated U, U/Th and TOC, $S_{2}$, \%Ca is divided into two parts, and every part is positive (Figure 9).
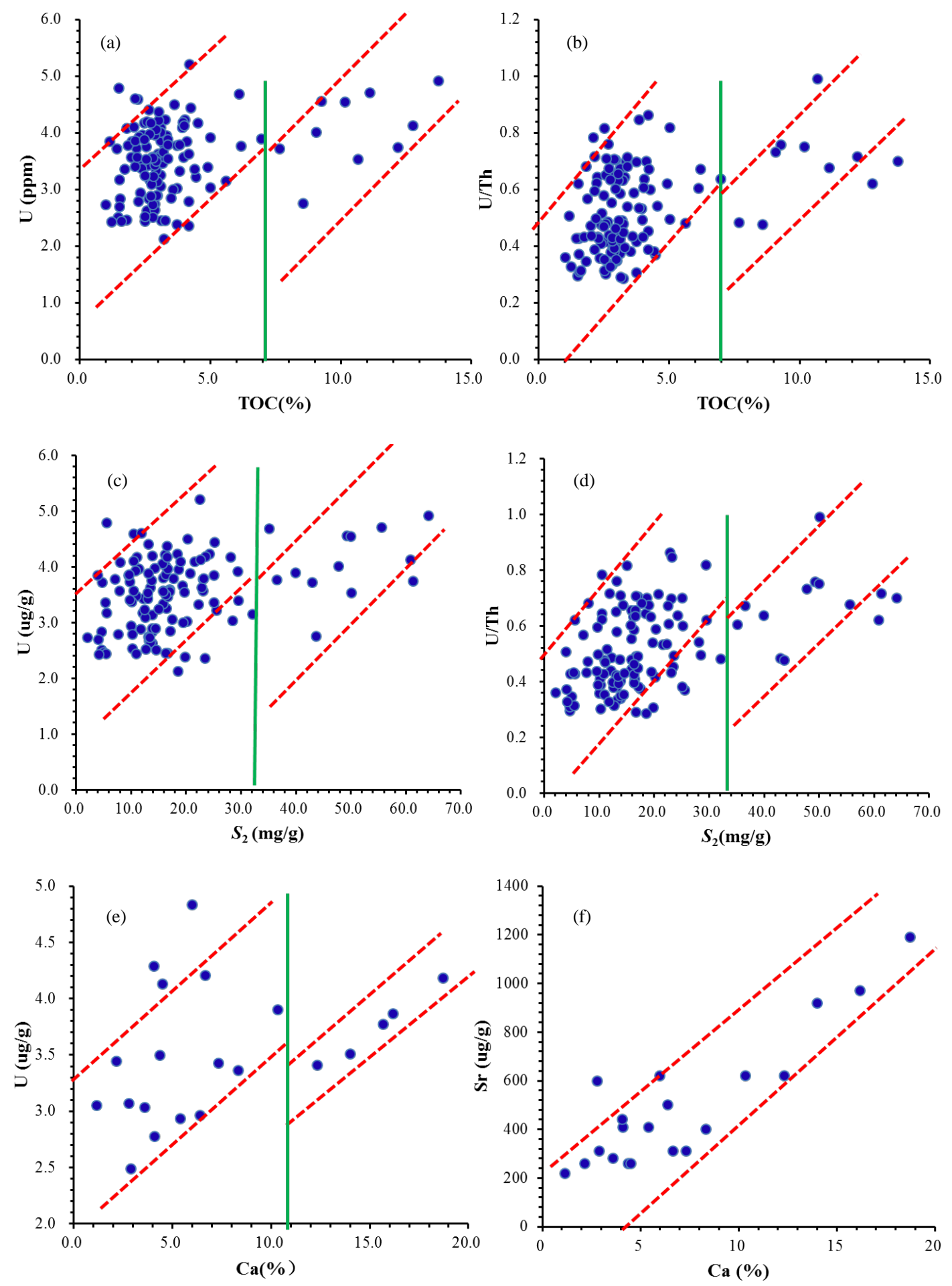

Figure 9. Quantitative correlations of U, U/Th to TOC, $S_{2}$, and Ca\% in the Niu-38 well at depths 3190 - $3376 \mathrm{~m}$. 
The second part with higher $U$ enrichment is separated from the first part in the boundary values of $7.0 \%$, 32 $\mathrm{mg} / \mathrm{g}$ and $11 \%$ for the TOC, $S_{2}$ and \%Ca, respectively. The second part corresponding to the higher TOC, $S_{2}$ and \%Ca is almost for the oil shale samples. The obvious two separated quantitative relations imply that the $U$ enrichment in the oil shale is likely to be different from the U enrichment in the normal mudstone as they reflect different redox environments. The oxidation-reduction potential is the main factor in the reversible transformation between $\mathrm{U}^{4+}$ and $\mathrm{U}^{6+}$. The amount of $\mathrm{U}^{4+}$ that is absorbed to sediment surfaces can be reduced to absorbed $\mathrm{U}^{6+}$ phases [17]. Under oxic conditions, $\mathrm{U}^{4+}$ in rocks is oxidized into $\mathrm{U}^{6+}$, which is released into groundwater; hence, the U content of rocks decreases, while that of groundwater increases [12]. Under reduced conditions, $\mathrm{U}^{4+}$ is reduced to $\mathrm{U}^{6+}$ and precipitates; hence, the $\mathrm{U}$ content of groundwater decreases, while that of rocks increases [18].

\section{Conclusions}

The lacustrine mudstone and shales of the lower part of Paleogene Shahejie Formation from the N-38 well in Dongying depression were investigated with organic matter and element distribution. Most of the samples show high TOC and $S_{2}$, with TOC and $S_{2}$ greater than $2.0 \%$ and $10.0 \mathrm{mg} / \mathrm{g}$, respectively; the oil shale samples show the TOC and $S_{2}$ are greater than $5.0 \%$ and $20.0 \mathrm{mg} / \mathrm{g}$, respectively. The organic matter was dominated with organic matter of type I, and some of II1 type, indicating most of samples are good source rocks and the oil shale are excellent source rocks. The lower value of biomarker ratio gammacerane $/ C_{30} \mathrm{H}$ and $\mathrm{C}_{35} \mathrm{H} / \mathrm{C}_{34} \mathrm{H}$ indicates a freshwater depositional environment in the deep lake.

The element geochemical data from the studied mudstone and shales reveal the response of certain major and trace elements related to the lake basin evolution, as the decrease in buried depth from $3330-3190 \mathrm{~m}$. The ratios $\mathrm{Ca} / \mathrm{U}, \mathrm{Ca} / \mathrm{Ba}, \mathrm{Ca} / \mathrm{Mg}, \mathrm{Ca} / \mathrm{B}, \mathrm{Ca} / \mathrm{Li}, \mathrm{Ca} / \mathrm{Sr}$ and $\mathrm{Sr} / \mathrm{Ba}$ overall gradually decrease, and $\mathrm{Fe} /(\mathrm{Ca}+\mathrm{Mg})$ increases. In the section 3330 - $3370 \mathrm{~m}$ with the oil shale developed, the geochemistry of organic matter and element suggest a reducing depositional environment with strong fluctuation.

The data here provided quantitative relations between the elevated U, U/Th and TOC, $S_{2}$, \%Ca. An interesting observation is that the correlation between the elevated U, U/Th and TOC, $S_{2}, \%$ Ca is divided into two parts, and the boundary values of $7.0 \%, 32 \mathrm{mg} / \mathrm{g}$ and $11 \%$ for the TOC, $S_{2}$ and \%Ca, respectively. The obvious two separated quantitative relations imply that the $\mathrm{U}$ enrichment is different in the oil shale and the normal mudstone as they reflect different redox environments.

\section{Acknowledgements}

This study was co-supported by the National Natural Science Foundation of China (Grants No. 41272140 and 41372129), the Fundamental Research Fund for the Central Universities, and the China Postdoctoral Science Foundation (2015M571227). We thank the Shengli Oil Company of Sinopec for their collaboration in this study.

\section{References}

[1] Chen, Z.H. and Zha, M. (2006) Sedimentary Characteristics of Source Rocks in Fluctuation from Lake Facies: An Example from Dongying Depression, China. Journal of Lake Science, 18, 29-35.

[2] Chen, Z.H. and Zha, M. (2008) Mechanism of Overpressured Fluid Compartment and Its Controlling on Hydrocarbon Migration and Accumulation in Faulted Lacustrine Basin: A Case Study from the Dongying Sag, Bohai Bay Basin. Chinese Journal of Geology, 43, 50-64.

[3] Chen, Z.H., Zha, M. and Jin, Q. (2008) Mineral Element al Response to the Evolution of Terrestrial Brine FaultedBasin: A Case Study in the Paleogene of Well Haoke-1, Dongying Sag. Acta Sedimentologica Sinica, 26, 924-932.

[4] Moon, H.S., Komlos, J. and Jaffe, P.R. (2007) Uranium Reoxidation in Previously Bioreduced Sediment by Dissolved Oxygen and Nitrate. Environmental Science \& Technology, 41, 4587-4592. http://dx.doi.org/10.1021/es063063b

[5] Regenspurg, S., Margot-Roquier, C., Harfouche, M., Froidevaux, P., Steinmann, P., Junier, P. and Bernier-Latmani, R. (2010) Speciation of Naturally-Accumulated Uranium in an Organic-Rich Soil of an Alpine Region (Switzerland). Geochimicaet Cosmochimica Acta, 74, 2082-2098. http://dx.doi.org/10.1016/j.gca.2010.01.007

[6] Mehta, V.S., Maillot, F., Wang, Z.M., Catalano, J.G. and Giammar, D.E. (2014) Effect of Co-Solutes on the Products and Solubility of Uranium (VI) Precipitated with Phosphate. Chemical Geology, 364, 66-75.

http://dx.doi.org/10.1016/j.chemgeo.2013.12.002 
[7] Demaison, G.J. and Moore, G.T. (1980) Anoxic Environments and Oil Source Bed Genesis. Organic Geochemistry, 2, 9-31. http://dx.doi.org/10.1016/0146-6380(80)90017-0

[8] Talbot, M.R. and Johannessen, T. (1992) A High Resolution Palaeoclimatic Record for the Last 27,500 Years in Tropical West Africa from the Carbon and Nitrogen Isotopic Composition of Lacustrine Organic Matter, Earth Planet. Science Letters, 110, 23-37. http://dx.doi.org/10.1016/0012-821X(92)90036-U

[9] Lyons, R.P., Scholz, C.A., Buoniconti, M.R. and Martin, M.R. (2011) Late Quaternary Stratigraphic Analysis of the Lake Malawi Rift, East Africa: An integration of Drillcore and Seismic-Reflection Data. Palaeogeography, Palaeoclimatology, Palaeoecology, 303, 20-37. http://dx.doi.org/10.1016/j.palaeo.2009.04.014

[10] Sharp, J.O., Lezama-Pacheco, J.S., Schofield, E.J., Junier, P., Ulrich, K.-U., Chinni, S., Veeramani, H., MargotRoquier, C., Webb, S.M., Tebo, B.M., Giammar, D.E., Bargar, J.R. and Bernier-Latmani, R. (2011) Uranium Speciation and Stability after Reductive Immobilization in Aquifer Sediments. Geochimica et Cosmochimica Acta, 75, 6497-6510. http://dx.doi.org/10.1016/j.gca.2011.08.022

[11] Fletcher, K.E., Boyanov, M.I., Thomas, S.H., Wu, Q., Kemner, K.M. and Loeffler, F.E. (2010) U(VI) Reduction to Mononuclear U(IV) by Desulfitobacterium Species. Environmental Science \& Technology, 44, 4705-4709. http://dx.doi.org/10.1021/es903636c

[12] McManus, J., Berelson, W.M., Klinkhammer, G.P., Hammond, D.E. and Holm, C. (2005) Authigenic Uranium: Relationship to Oxygen Penetration Depth and Organic Carbon rain. Geochimicaet Cosmochimica Acta, 69, 95-108. http://dx.doi.org/10.1016/j.gca.2004.06.023

[13] Holba, A.G., Dzou, L.I., Wood, G.D., Ellis, L., Adam, P., Schaeffer, P., Albrecht, P., Greene, T. and Hughes, W.B. (2003) Application of Tetracyclic Polyprenoids as Indicators of Input from Fresh-Brackish Water Environments. Organic Geochemistry, 34, 441-469. http://dx.doi.org/10.1016/S0146-6380(02)00193-6

[14] Summons, R.E., Hope, J.M., Swart, R. and Walter, M.R. (2008) Origin of Nama Basin Bitumen Seeps: Petroleum Derived from a Permian Lacustrine Source Rock Traversing Southwestern Gondwana. Organic Geochemistry, 39, 589607. http://dx.doi.org/10.1016/j.orggeochem.2007.12.002

[15] Restituito, E. (1987) Consequences of Redox Conditions on the Distribution of Cations in a Meromictic Oligotrophic Lake. Hydrobiologia, 144, 63-75. http://dx.doi.org/10.1007/BF00008052

[16] Mills, C.T., Amano, Y., Slater, G.F., Dias, R.F., Lwatsuki, T. and Mandernack, K.W. (2010) Microbial Carbon Cycling in Oligotrophic Regional Aquifers near the Tono Uranium Mine, Japan as Inferred from $\delta^{13} \mathrm{C}$ and $\Delta^{14} \mathrm{C}$ Values of in Situ Phospholipid Fatty Acids and Carbon Sources. Geochimicaet Cosmochimica Acta, 74, 3785-3805. http://dx.doi.org/10.1016/j.gca.2010.03.016

[17] Begg, J.D.C., Burke, I.T., Lloyd, J.R., Boothman, C., Shaw, S., Charnock, J.M. and Morris, K. (2011) Bioreduction Behavior of U(VI) Sorbed to Sediments. Geomicrobiology Journal, 28, 160-171. http://dx.doi.org/10.1080/01490451003761137

[18] Senko, J.M., Kelly, S.D., Dohnalkova, A.C., McDonough, J.T., Kemner, K.M. and Burgos, W.D. (2007) The Effect of $\mathrm{U}(\mathrm{VI})$ Bioreduction Kinetics on Subsequent Reoxidation of Biogenic U(IV). Geochimica et Cosmochimica Acta, 71, 4644-4654. http://dx.doi.org/10.1016/j.gca.2007.07.021 